\title{
Caecum Volvulus: A Short Case Series
}

\author{
Duncan D Mugala ${ }^{1}$, Alick Mwambungu ${ }^{2}$, Nathan Siulapwa ${ }^{3}$, Womba Kadochi ${ }^{4}$ Muhumpu Kafwamfwa $^{5}$ \\ ${ }^{1}$ BSc, MB ChB, M Med (Surgery), FCS (ecsa), Senior Consultant General Surgeon, Nchanga South Hospital, Chingola.(Retired), Senior \\ Consultant Surgeon Ndola Central Hospital, Senior Lecturer Copper Belt University School of Medicine Honorary Lecturer University of \\ Zambia School of Medicine, Ndola Central Hospital 6th Eastwing PO Box 21629 Ndola \\ ${ }^{2}(\mathrm{BSc}, \mathrm{MSc})$ Lecturer Ndola College of Biomedical Sciences
}

${ }_{3}^{3}$ (BSc, MSc, PhD) Head-Basic Sciences Copper Belt University School of Medicine.(The Late)

${ }^{4} \mathrm{BSc} \mathrm{HB}, \mathrm{MB}, \mathrm{ChB}$ Registrar Surgery, Copperbelt University, Ndola Central Hospital, Ndola

${ }^{5}$ BSc, MB ChB, M Med (General Surgery), Consultant Surgeon Kabwe General Hospital,Kabwe, Zambia

\begin{abstract}
Caecal volvulus is an infrequently encountered clinical condition and an uncommon cause of intestinal obstruction. Patients with this condition may present with highly variable clinical presentations ranging from intermittent, self limiting abdominal pain to acute abdominal pain associated with intestinal strangulation and sepsis. Lack of familiarity with this condition is a factor contributing to diagnostic and treatment delays. Sigmoid volvulus is one of the most common presentation in Zambia and yet those of Caecum volvulus are a rare condition, but they do occur some times. In the study of the Caecum Volvulus cases over the 15 years we saw a total of 16 patients who needed surgery. There were 10 females and 6 males who presented to us needing Caecal surgery. The youngest was 17 years old and the oldest was 84 years old (the mean age being 42 year age).The most common abdominal problem was abdominal distension and abdominal pain. In our study we had more females than males and nearly all the patients had a large floating redundant Caecum. Excision of the Caecum and Ileo-colic anastomosis was done on the patients. The outcome in all the patients was good. We hypothesize that despite a possible anatomic predisposition of Caecal Volvulus in certain Zambian individuals, the exact etiology is most likely multi-factorial. Cadaveric studies of the long Caecum in Zambians need to be carried out to prove or disapprove this hypothesis.
\end{abstract}

Keywords: Caecum, distension, hemicolectomy, Volvulus

\section{Introduction}

Caecal volvulus as an uncommon cause of acute intestinal obstruction is the rotation or torsion of a flexible caecum and ascending colon, frequently progressing to bowel obstruction, ischemia, necrosis, and perforation. Volvuli can occur at other sites in the alimentary tract, including the sigmoid colon, stomach, gallbladder, splenic flexure, and small bowel. Sigmoid volvulus is one of the most common presentations in Zambia and yet those of Caecum volvulus are rare. Although there are many different etiologic and predisposing factors causing volvulus, exact etiology is most likely multifactorial in presence of mobile caecum. Its clinical presentation is highly variable, ranging from intermittent episodes of abdominal pain to an abdominal disaster depending on pattern, severity and duration of caecal volvulus causing intestinal obstruction. Due to its rarity and nonspecific presentation, preoperative diagnosis is rarely achieved in Zambian cases. Resection with right hemicolectomy and primary Ileo-colic anastomosis has been recommended for surgical treatment of caecal volvulus.

This report serves to remind us that Caecum volvulus though rare does occur.

\subsection{Patients and Methods}

This was a prospective study in which all cases of patients presenting with Caecal Volvulus at Ndola Central Hospital and Nchanga Mine Hospital from June 2000 to June 2015 were recorded and analyzed. The first case was that encountered in January 2000 and this made us follow up and record any such cases from June 2000 onwards.

\section{Results}

Over the past 15 years we saw a total of 16 patients who needed surgery. There were 10 females and 6 males who presented to us needing caecal surgery. The youngest was 17 years old and the oldest was 84 years old (the mean age being 42 year age). The most common abdominal problem was abdominal distension and abdominal pain. Three patients had abdominal pain for about five years. Seven patients had the pain for over one year. Three patients gave us a history of pain for about one month duration. Three patients complained of abdominal pain for just over one week (See Table I).

Fifteen patients presented with abdominal pain as their major complaints. However we did have six patients who had also Distension with Constipation. Three patients had a mass in the abdomen. One patient had intestinal obstruction for over one week. (See Table I).

Patients' duration of illness varied from over five years in two patients, over one year in eight patients, over one month in two patients and over one week in five patients. (See Table I).

All the 16 patients operated on, had a large floating redundant Caecum. There was also scarring at the bases of caecum (see Table II). The excision of the Caecum and the Ileo-colic anastomosis was done. In One patient there was partial gangrene of the caecum (see Table III). 


\section{International Journal of Science and Research (IJSR) \\ ISSN (Online): 2319-7064 \\ Index Copernicus Value (2013): 6.14 | Impact Factor (2014): 5.611}

One patient had paralytic ileus and stayed in the ward for 14 days. The majority were discharged quite early from the wards as is shown in table III.

\section{Discussion}

The term caecal volvulus is a misnomer because, in most patients with caecal volvulus, the torsion is located in the ascending colon above the ileocecal valve. In general, a partial malrotation is necessary for caecal volvulus to occur, because the cecum and parts of the ascending colon are involved. Early diagnosis is essential to reduce the high mortality rate reported with this condition, which is essentially a closed-loop obstruction that may lead to vascular compromise with consequent gangrene and

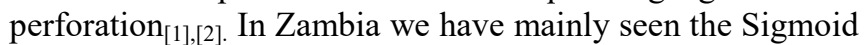
volvulus but in our town we have seen also the caecum Volvulus. The caecal volvulus (CV) as an uncommon cause of acute intestinal obstruction is the axial twist of the caecum, ascending colon, and terminal ileum around their mesenteric pedicles[3] Associated with this, we came across the scarring of many of the bases of the Caecum.

According to the several studies, CV accounts for 10-60\% of all colonic volvulus [1],[2],[4]. and can be divided into two major subgroups: the first is loop axial ileo-colic Volvulus, which accounts for $90 \%$ of cases. In our case the 16 cases we saw belonged to this group. The second is caecal bascule, which accounts for the remaining cases[1]. The classic ileo-colic Volvulus is a clockwise or counterclockwise rotation of the cecum with distal ileum in an oblique pattern. However, the counter clock-type is more commonly seen. In caecal bascule, there is an upward folding of the caecum, either anteriorly or posteriorly[8].

Etiology and predisposing factors for $\mathrm{CV}$ include chronic constipation, abdominal masses, late-term pregnancy, and previous abdominal surgery. In our case the major presentation were as follows: Fifteen patients presented with abdominal pain as their major complaints. Six patients also who had Distension with Constipation. Three patients had a mass in the abdomen.

Some patients may present with prolonged immobility, highfiber intake, paralytic ileus, and after a post colonoscopy effect[4],[7],[9],[12]. We strongly feel the high fiber intake is a common feature in our general population and some may present with Caecal problems. One patient presented with Paralytic ileus and the patient's hospital stay was a long one.

According to the clinical series published before, previous abdominal surgery was identified as an important contributing factor for formation of $\mathrm{CV}$, based on the fact that $23-53 \%$ of the patients presenting with $\mathrm{CV}$ have had a history of prior abdominal surgery.In all the 16 cases, our patient had no previous surgery in their presentations. This was the only surgery they ever had. However, this finding has not been observed as an important cause for development of CV in other studies[7],[10],[11].

During embryologic development of the colon, fixation to posterior parietal peritoneum occurs following normal anatomical rotation of $270^{\circ}$, but development of deficient fixation with normal rotation or elongation of the colon caused by over-rotation causes mobile Caecum[8]. It is commonly believed that a mobile Caecum with lack of fixation of the right colon, Caecum, terminal ileum, and mesentery to the posterior parietal peritoneum is primarily required for $\mathrm{CV}$ to occur. Our patients belonged to this type of presentation.

We believe that despite this possible anatomic predisposition in certain Zambian individuals, the exact etiology is most likely multi factorial[1]

The incidence of $\mathrm{CV}$ varies according to the presence of the mobile Caecum, which can be found to be present in almost $25 \%$ of the general population based on cadaveric examinations and the other predisposing factors[14]. We have not carried out Cadaveric studies of the long Caecum in Zambia and we look forward to prove this fact. However studies carried out on the Sigmoid colon has shown that the Sigmoid colon in Africans is prolonged[13]. Like in Black Zambians this is true. Because of the issues mentioned above, exact incidence varies widely from 2.8 to 7.1 per million people per year in different regions:

Patients' age at presentation is affected by several geographical and dietary influences and their effects on intestinal motility. The average age in developed countries was around 50-65 years, however $\mathrm{CV}$ has been reported in younger age groups in Far East countries. In Zambia the age range was from a young age of 17 years old and the oldest being of 84 years of age (the mean age being 42 years age).

Female or male predominance was also reported in several reports[3],[6]. In Zambia, over the 15 years we saw a total of 16 patients who needed surgery; there were 10 females and 06 males who presented to us needing Caecal surgery.

The small number of the CV cases we have reported and those also small cases from different geographical regions may cause this contradiction with regard to gender predominance

\subsection{Conclusion}

In our study we had more female patients than male patients and nearly all the patients had a large floating redundant Caecum. Scarring at the bases of Caecum in most patients was observed. Excision of the Caecum and Ileo-colic anastomosis was done on the patients. The outcome in all the patients was good. We hypothesize that despite a possible anatomic predisposition of Caecal Volvulus in certain Zambian individuals, the exact etiology is most likely multi-factorial. Cadaveric studies of the long Caecum in Zambians need to be carried out to prove or disapprove this hypothesis. In conclusion, the occurrence of $\mathrm{CV}$ is a multifactorial process in the presence of abnormally mobile caecum. Prompt recognition and urgent treatment may avoid gangrenous changes of the bowel. Although abdominal radiographs should play an important role in early diagnosis, computed tomography can be considered for definitive diagnosis of CV. Resection and primary anastomosis is the 


\section{International Journal of Science and Research (IJSR) \\ ISSN (Online): 2319-7064 \\ Index Copernicus Value (2013): 6.14 | Impact Factor (2014): 5.611}

treatment of the operation depending on the general condition of the patient.

\section{References}

[1] Madiba TE, Thomson SR. The management of cecal volvulus. Dis Colon Rectum. 2002;45:264-267. doi: 10.1007/s10350-004-6158-4.

[2] Valsdottir E, Marks JH. Volvulus: small bowel and colon. Clin Colon Rectal Surg. 2008;2:91- 93. doi: 10.1055/s-2008-1075856.

[3] Majeski J. Operative therapy for cecal volvulus combining resection with colopexy. Am J Surg. 2005;189:211-213. doi: 10.1016/j.amjsurg.2004.11.004.

[4] Consorti ET, Liu TH. Diagnosis and treatment of caecal volvulus. Postgrad Med J. 2005;81:772-776. doi: 10.1136/pgmj.2005.035311.

[5] Mulas C, Bruna M, García-Armengol J, Roig JV. Management of colonic volvulus. Experience in 75 patients. Rev Esp Enferm Dig. 2010;102:239-248. doi: 10.4321/S1130-01082010000400004.

[6] Lau KC, Miller BJ, Schache DJ, Cohen JR. A study of large-bowel volvulus in urban Australia. Can J Surg. 2006;49:203-207.

[7] Ballantyne GH, Brandner MD, Beart RW, Jr, Ilstrup DM. Volvulus of the colon. Incidence and mortality.
Ann Surg. 1985;202:83-92. doi: 10.1097/00000658198507000-00014. [

[8] Tirol FT. Cecocolic torsion: classification, pathogenesis, and treatment. JSLS. 2005;9:328-334.

[9] Katoh T, Shigemori T, Fukaya R, Suzuki H. Cecal volvulus: report of a case and review of Japanese literature. World J Gastroenterol. 2009;15:2547-2549. doi: 10.3748/wjg.15.2547.

[10]Neil DA, Reasebeck PG, Reasbeck JC, Effeney DJ. Caecal volvulus: ten year experience in an Australian teaching hospital. Ann R Coll Surg Engl. 1987;69:283285.

[11] Ruiz-Tovar J, Calero García P, Morales Castiñeiras V, Martínez Molina E. Caecal volvulus: presentation of 18 cases and review of literature. Cir Esp. 2009;85:110 113. doi: 10.1016/j.ciresp.2008.09.003.

[12] Tuech JJ, Pessaux P, Regenet N, Derouet N, Bergamaschi R, Arnaud JP. Results of resection for volvulus of the right colon. Tech Coloproctol. 2002;6:97-99. doi: 10.1007/s101510200021.

[13] Akinkuotu A, Samuel JC , Musiska N, Mvula C, Charle AG.The role of the Anatomy of the sigmoid Colon in Developing Sigmoid Volvulus: A case-control study. Clin Anat.2011 Jul;24(5):634-637.

Tables

Table I: Presenting Complaints of Patients found to have Caecum volvulus

\begin{tabular}{|c|c|c|c|c|}
\hline Code & Sex & Age & Complaints & Duration \\
\hline 1 & M & 47 & Abdominal pain, flatulence, constipation & $>1$ year \\
\hline 2 & F & 48 & Abdominal pain, Weight loss, visible peristalsis, constipation & $>1$ year \\
\hline 3 & F & 34 & Abdominal pain, Distension, Constipation & 1 week \\
\hline 4 & F & 40 & Abominal pain, Distension, Constipation & 1 week \\
\hline 5 & F & 36 & Abdominal pain, constipation, Abdominal masses & $>1$ year \\
\hline 6 & M & 17 & Abdominal pain, constipation, abdominal masses & $>1$ year \\
\hline 7 & F & 38 & Abdominal pain & $>1$ year \\
\hline 8 & F & 21 & Abdominal pain, Backache, Patient also had Breast cancer & $>1$ year \\
\hline 9 & F & 43 & Intermittent Abdominal Pain & $>1$ years \\
\hline 10 & F & 19 & Mass in abdomen & $>1$ month \\
\hline 11 & M & 53 & Intestinal obstruction & $>1$ week \\
\hline 12 & F & 43 & Abdominal pain & $>1$ year \\
\hline 13 & M & 54 & Severe Lower abdominal pain & $>1$ week \\
\hline 14 & M & 84 & Right iliac fossa pain & $>1$ month \\
\hline 15 & M & 55 & Distended abdomen & $>5$ years \\
\hline 16 & F & 40 & Pain in lower abdomen & $>5$ years \\
\hline
\end{tabular}

Table II: Clinical Features and Findings

\begin{tabular}{|c|c|c|c|}
\hline S/No & Abdominal Findings & Investigations & $\begin{array}{c}\text { Surgical Findings } \\
\end{array}$ \\
\hline 1 & \begin{tabular}{c|} 
Right Iliac Fossa \\
Gaseous distension
\end{tabular} & $\begin{array}{c}\text { US scan routines } \\
\text { CT }\end{array}$ & $\begin{array}{c}\text { Large and redundant Caecum } \\
\text { Lots of scarring at the base of the Caecum }\end{array}$ \\
\hline 2 & $\begin{array}{c}\text { Anaemia on Routine } \\
\text { Investigations }\end{array}$ & Abdominal X-rays & $\begin{array}{c}\text { Large floating Caecum } \\
\text { Big cervix bleeding biopsy taken }\end{array}$ \\
\hline 3 & Whole abdomen & $\begin{array}{l}\text { Routine X-rays } \\
\text { Intestinal obstruction } \\
\text { Low sodium } \\
\text { Raised urea }\end{array}$ & $\begin{array}{c}\text { Sigmoid volvulus with impending gangrene } \\
\text { Volvulus of floating caecum with impending rapture and gangrene } \\
\text { Scarring the bases of caecum and Sigmoid colon } \\
\text { Pregnant Uterus } 16 \text { wks size }\end{array}$ \\
\hline 4 & Whole abdomen & $\begin{array}{l}\text { Intestinal obstruction } \\
\text { Raised urea }\end{array}$ & Large floating caecum volvulus no gangrene \\
\hline 5 & Whole abdomen & $\begin{array}{l}\text { X-rays suggestive of worm } \\
\text { infestation Low } \mathrm{Hb} \\
\mathrm{U} \& \mathrm{E} \text { was normal } \\
\text { In addition to small bowel tumour }\end{array}$ & $\begin{array}{l}\text { There was a floating Caecum } \\
\text { There was intussusception of the ileum }\end{array}$ \\
\hline
\end{tabular}




\section{International Journal of Science and Research (IJSR) \\ ISSN (Online): 2319-7064}

Index Copernicus Value (2013): 6.14 | Impact Factor (2014): 5.611

\begin{tabular}{|c|c|c|c|}
\hline 6 & whole abdomen & Planned for Cholecystectomy & At Cholecystectomy a floating Caecum was found \\
\hline 7 & Right Iliac Fossa & X-Rays were normal & $\begin{array}{c}\text { Fibroid Uterus } \\
\text { Floating Caecum } \\
\text { Adhesions around the appendix }\end{array}$ \\
\hline 8 & Right Iliac Fossa & $\begin{array}{l}\text { U/sound scan showed Retroverted } \\
\text { Uterus Routines were normal }\end{array}$ & $\begin{array}{l}\text { Large and redundant Caecum } \\
\text { Lots of scarring at the base of the Caecum }\end{array}$ \\
\hline 9 & Right Lumber Area & $\begin{array}{c}\text { U/sound scan showed a cystic mass } \\
\text { Routines were normal }\end{array}$ & $\begin{array}{c}\text { Long redundant caecum } \\
\text { Dermoid cyst from fundus of uterus }\end{array}$ \\
\hline 10 & $\begin{array}{l}\text { Lower Abdominal } \\
\text { Pain }\end{array}$ & $\begin{array}{c}\text { X-Rays showed fluid levels } \\
\text { High Urea }\end{array}$ & $\begin{array}{l}\text { Long redundant Caecum } \\
\text { Necrosis of small bowel }\end{array}$ \\
\hline 11 & $\begin{array}{l}\text { Right Iliac Fossa } \\
\text { Mass Right Iliac } \\
\text { Fossa }\end{array}$ & US scan Routines were normal & $\begin{array}{c}\text { Long redundant Caecum } \\
\text { Long redundant Sigmoid colon } \\
\text { Lots of scarring at the base of the Caecum } \\
\text { Lots of scarring at the base of the sigmoid }\end{array}$ \\
\hline 12 & Lower abdomen & $\begin{array}{l}\text { US scan NAD } \\
\text { Routines Normal }\end{array}$ & $\begin{array}{l}\text { Long redundant Caecum } \\
\text { Lots of scarring at the base of the Caecum } \\
\text { Redundant Caecum in Torsion Appendix was normal }\end{array}$ \\
\hline 13 & Right Iliac Fossa & $\begin{array}{c}\text { Us Scan NAD } \\
\text { Routines Normal } \\
\end{array}$ & Redundant Caecum in Torsion Appendix was normal \\
\hline 14 & Right Iliac distension & $\begin{array}{l}\text { X-Ray showed Sigmoid Volvulus } \\
\text { US Scan not done }\end{array}$ & $\begin{array}{l}\text { Sigmoid Volvulus with large Transverse colon } \\
\text { Also had a long Caecum no surgery done }\end{array}$ \\
\hline 15 & Distended Abdomen & $\begin{array}{c}\text { X-Ray showed Sigmoid Volvulus } \\
\text { US Scan not done }\end{array}$ & $\begin{array}{c}\text { Sigmoid Volvulus } \\
\text { Also had a long Caecum no surgery done }\end{array}$ \\
\hline 16 & Distended Abdomen & $\begin{array}{c}\text { Barium Meal showed long Stomach } \\
\text { ? Gastric distension }\end{array}$ & $\begin{array}{l}\text { Stomach not very distended } \\
\text { Long Redundant Caecum }\end{array}$ \\
\hline
\end{tabular}

Table III. Patients operated upon for Caecum volvulus

\begin{tabular}{|c|c|c|}
\hline S/NO. & Procedures & Outcome \\
\hline 1 & Excision of the Caecum Ileo-colic anastomosis & $\begin{array}{c}\text { Scar pain only } \\
\text { continued }\end{array}$ \\
\hline 2 & Excision of the Caecum, Ileo-colic anastomosis & Ileo-colic anastomosis \\
\hline 3 & Sigmoidectomy with Primary anastomosis, Excision of the caecum & Patient well and discharged 5th day \\
\hline 4 & Excision of caecum, Ileo-colic anastomosis & $\begin{array}{c}\text { Patient discharged on the } 8^{\text {th }} \text { day. Diffuse } \\
\text { small cell lymphoma, Treated with COP }\end{array}$ \\
\hline 5 & Excision of the tumors, caecum was not excised & Caecum was not excised, Discharged 8 th day \\
\hline 6 & Cholecystectomy was done & Discharged on $5^{\text {th }}$ Day \\
\hline 7 & Appendicectomy was done and Caecum excised \\
\hline 8 & Caecum was excised Ileo-colic anastomosis & Discharged on $7^{\text {th }}$ Day \\
\hline 9 & Caecum not excised but mass removed & Discharged on $10^{\text {th }}$ Day \\
\hline 10 & Small bowel resected, Caecum left alone & Discharged on $14^{\text {th }}$ Day \\
\hline 11 & Caecum and Sigmoid colon excised, & Discharged on $5^{\text {th }}$ Day \\
\hline 12 & Patient had paralytic ileus post-operatively & Discharged on $5^{\text {th }}$ Day \\
\hline 13 & Caecum excised & Discharged on $5^{\text {th }}$ days \\
\hline 14 & Caecopexy was done & Discharged on $7^{\text {th }}$ day \\
\hline 15 & Caecum and transverse colon left with no Surgery, \\
\hline
\end{tabular}

Figures.

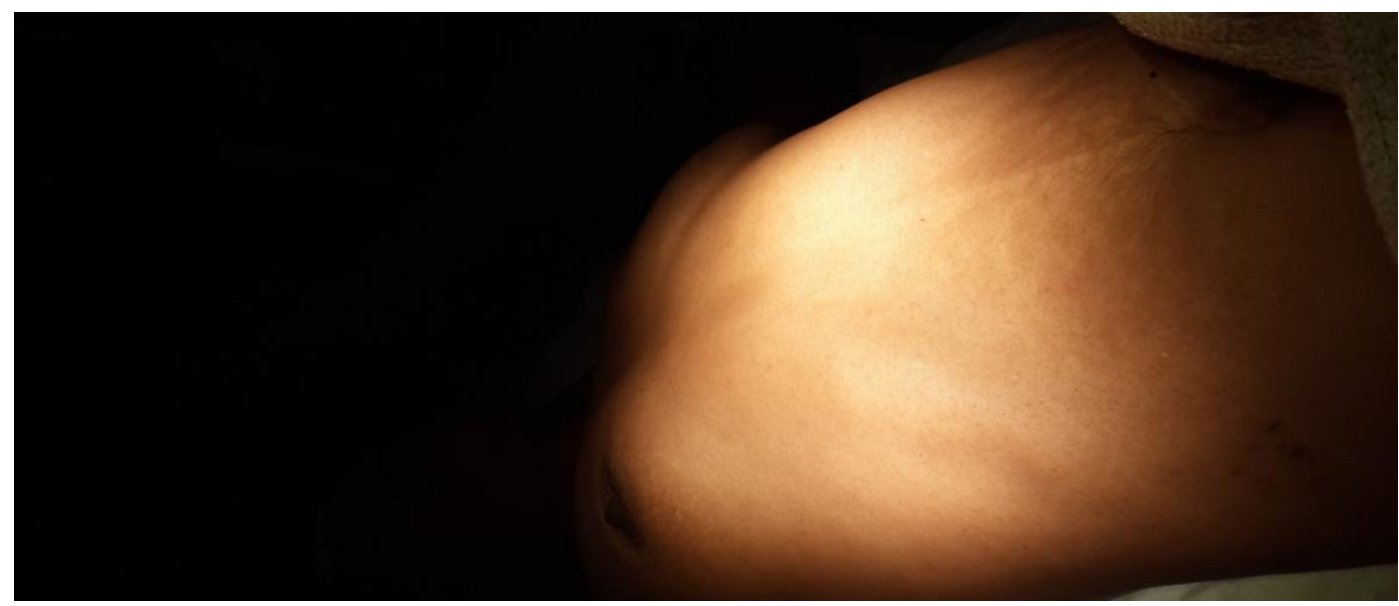

Figure 1: Patient presented with a large abdominal distension

Volume 5 Issue 2, February 2016 www.ijsr.net 
International Journal of Science and Research (IJSR)

ISSN (Online): 2319-7064

Index Copernicus Value (2013): 6.14 | Impact Factor (2014): 5.611

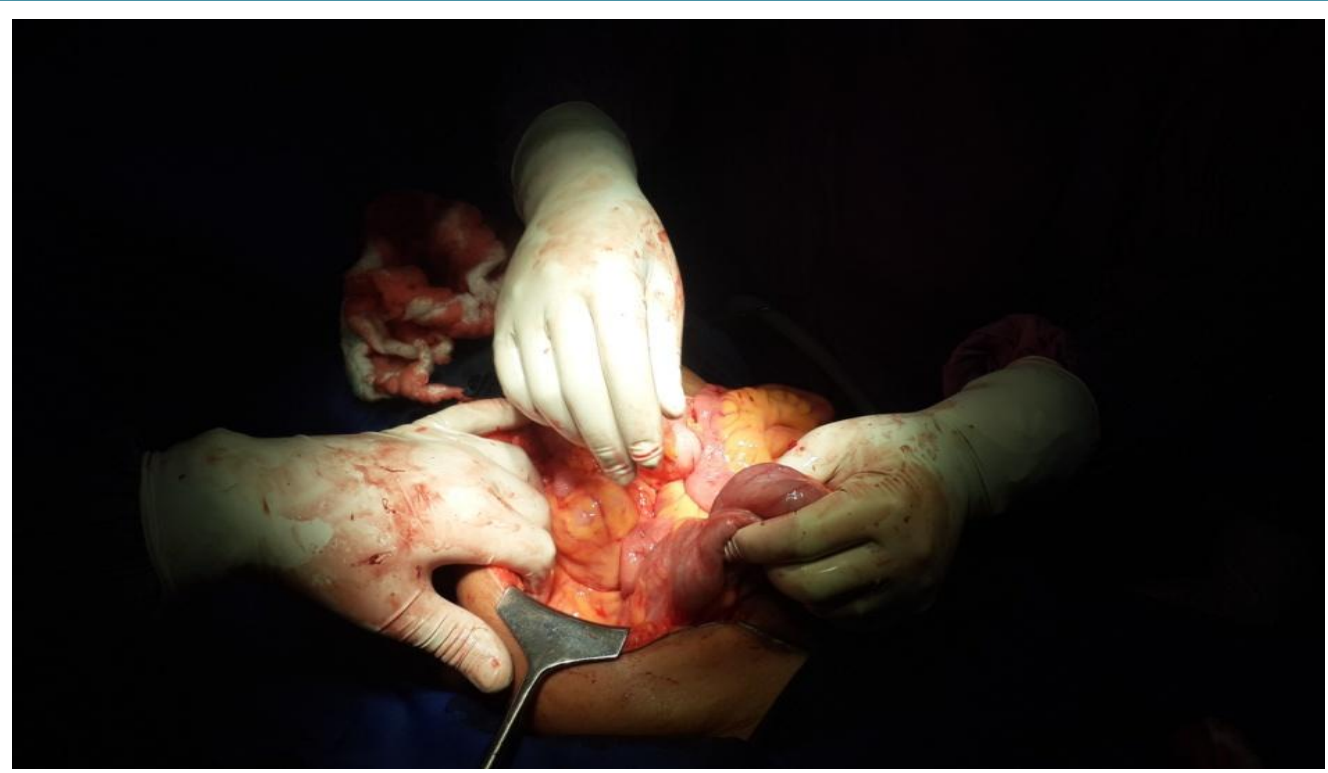

Figure 2: A long caecum in torsion

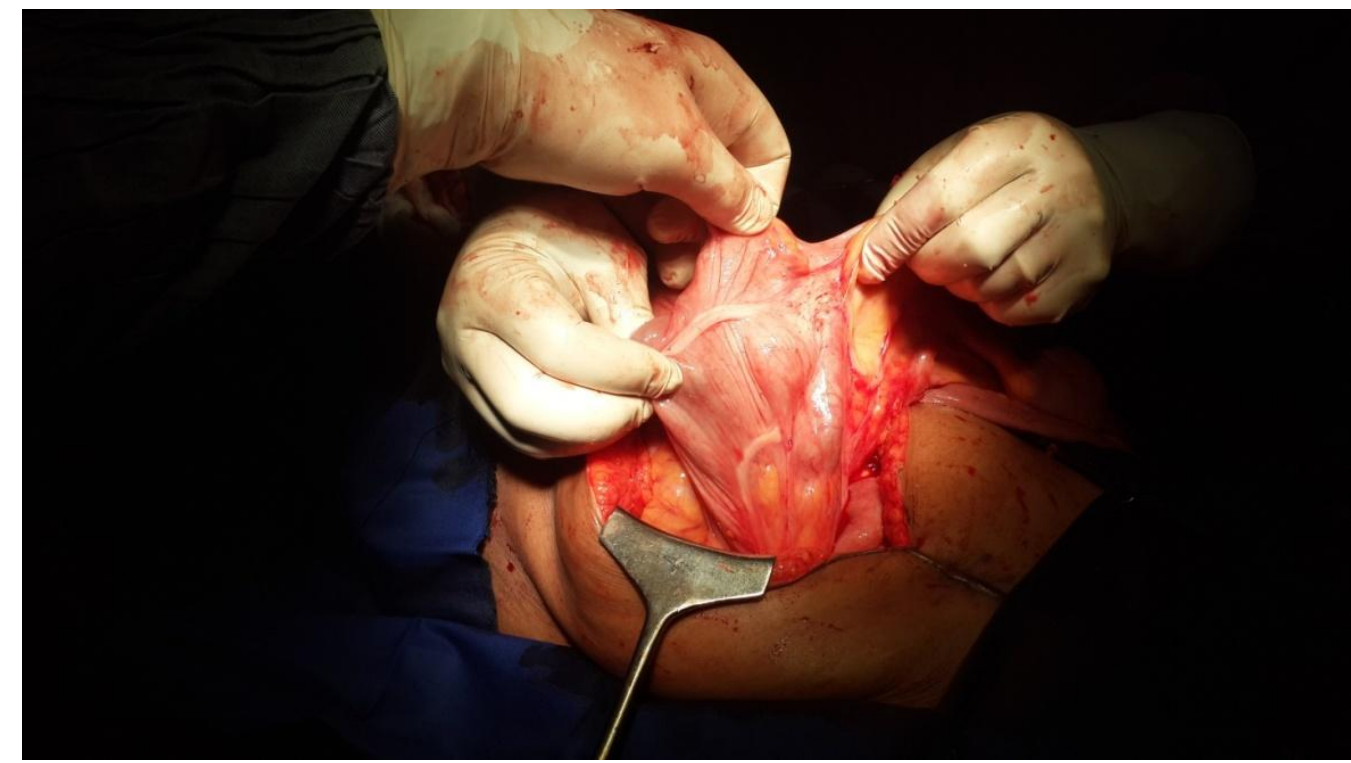

Figure 3: A long caecum

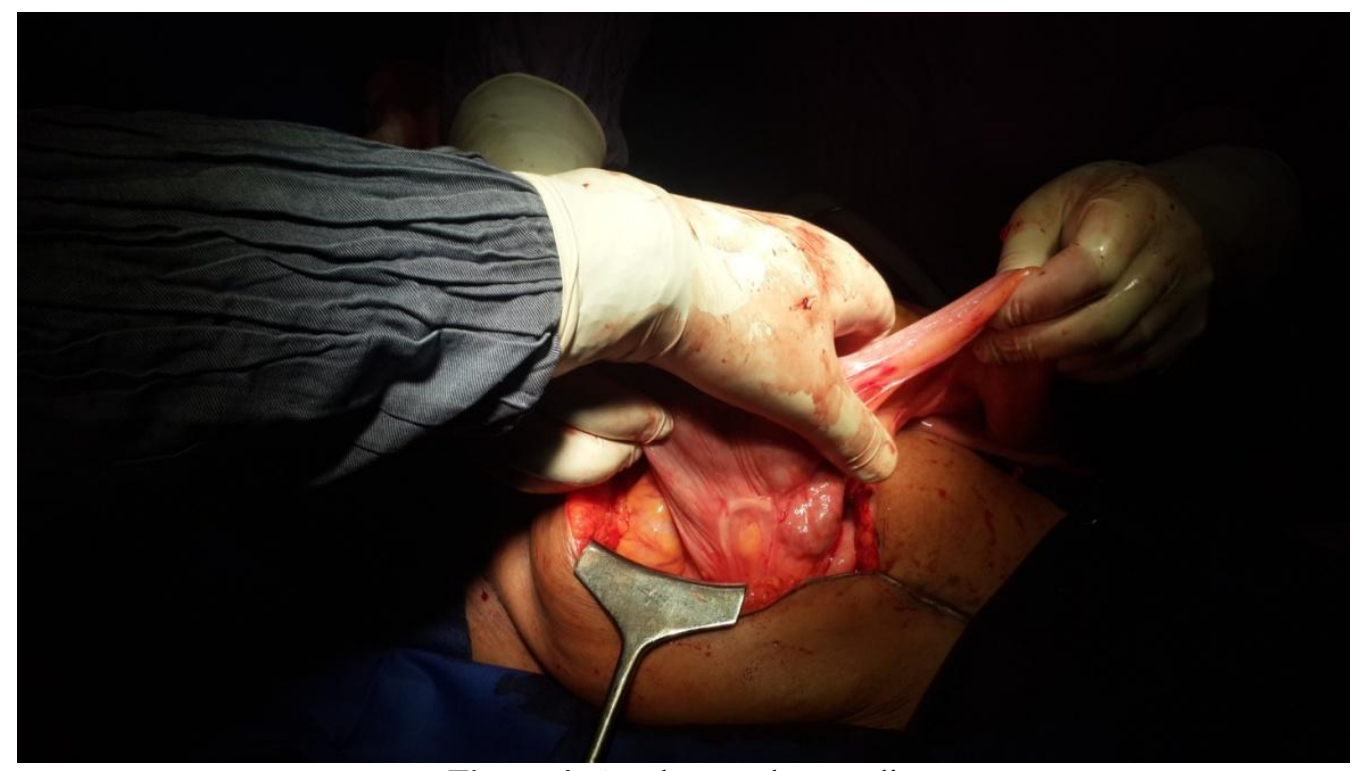

Figure 4: An elongated appendix

Volume 5 Issue 2, February 2016

www.ijsr.net 


\section{International Journal of Science and Research (IJSR)}

ISSN (Online): 2319-7064

Index Copernicus Value (2013): 6.14 | Impact Factor (2014): 5.611

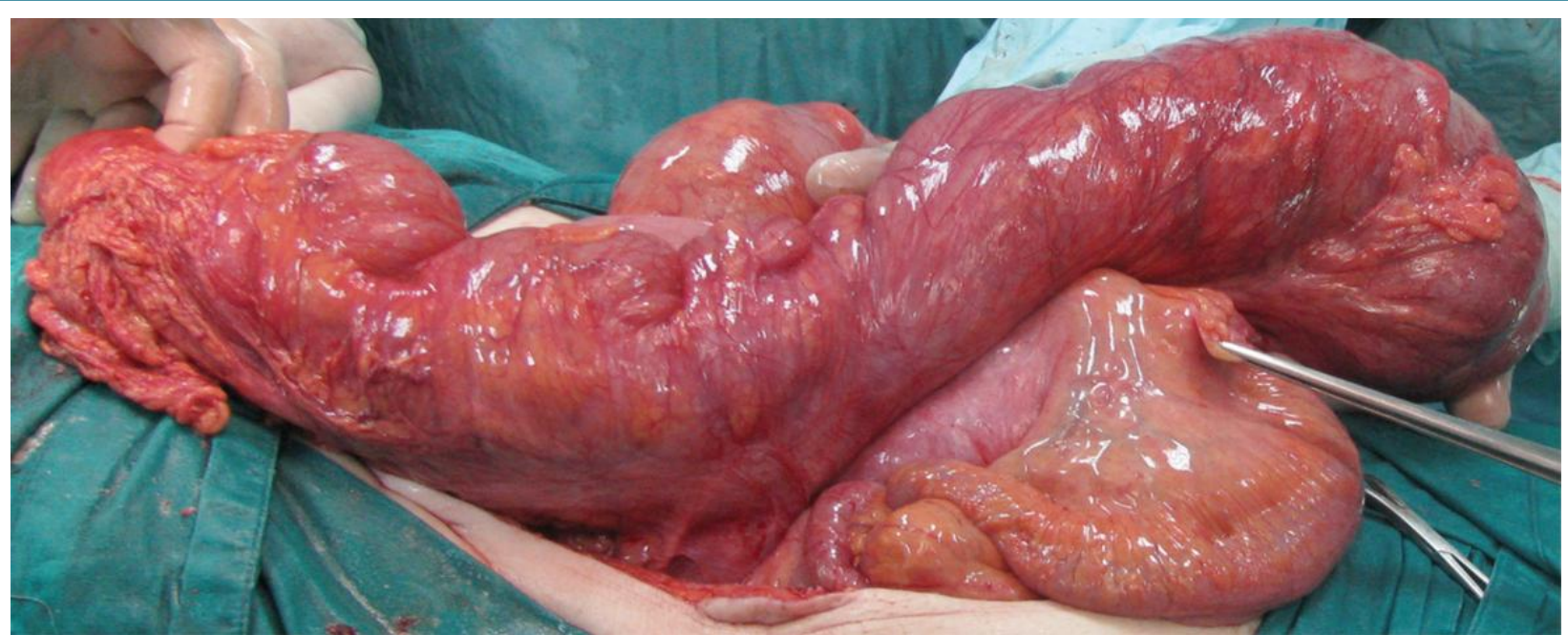

Figure 5: Intraoperative appearance of $\mathrm{CV}$ with minimal ischemic changes on the caecum.

Volume 5 Issue 2, February 2016

www.ijsr.net 